\title{
Lecturer Leadership in Influencing Learning Class Members Faced with the Covid-19 Pandemic Conditions
}

\author{
Tatar Bonar Silitonga \\ Indonesia Defense University \\ Email: tatarbonar@idu.ac.id
}

\begin{abstract}
This study is intended to analyze the leadership of lecturers in influencing members of the Civic Education learning class faced with the Covid-19 Pandemic. The discussion focused on controlling tactics used by lecturers in-class activities, including the initial stage, the running stage, to the final step. Qualitative methods are used to discuss the problem, and the data analysis approach is carried out using descriptive techniques. Data was collected using interviews with selected lecturers, observations, and literature studies. The process is complemented by the role of the researcher as the main instrument. The data results show that the influence tactics used by lecturers in their leadership are adjusted to existing conditions, including the initial stage, the running stage, and the final stage referring to the dynamics of the Covid-19 pandemic condition.
\end{abstract}

Keywords: Influence, Leadership, Lecturers, Covid-19 Pandemic.

\section{A. INTRODUCTION}

The Coronavirus Diseases (Covid-19) pandemic that has hit global life is no exception; Indonesia is also facing various fields. This problem is still a contextual challenge that is complicated and threatens multiple aspects of life. Chairani (2020) said that the Covid-9 pandemic severely impacted Indonesia's health, economy, and social structure. When detailed, the effect is quite complex and includes various dimensions. According to the World Health Organization (WHO), this disease spread rapidly to all parts of the world in a short time. Dissemination is identified as occurring as a result of displacement and human interaction. Until finally, on March 11, 2020, WHO declared Covid-19 a pandemic.

The spread of Covid-19 has been attempted with various solutions and policies. Implementing health protocols, large-scale social restrictions, and procedures to carry out vaccinations for citizens are also carried out. The vaccination process is still ongoing as of this writing. So far, the Covid-19 pandemic is still a threat. The impact is still influential in various aspects of life. It is necessary to harmonize the perceptions of multiple parties in supporting efforts to break the virus chain. In the solution effort, it is essential to think, and in that case, all components of the nation and various related aspects should play a role. The world of Indonesian education is no exception; it is expected to play a significant role. This role can be seen, among others, through higher education and various related elements in it. To break the chain of the spread of Covid-19, there is a demand for 
student learning activities to be carried out online (on the network / online). Online learning Online is defined as learning by utilizing computer networks connected to other computer networks throughout the world (Kitao in Riyana \& Pd., n.d). The community was previously used to being faced with offline learning activities (outside the network) or face-to-face activities directly and then replaced with online learning.

Online learning is understood to be different from face-to-face learning directly in the classroom. The difference can be seen based on the treatment of the multimedia system and the intensity of the meeting. In face-to-face learning directly, the role of multimedia is more complementary. While in the online model, the part of multimedia is the main. Furthermore, based on the intensity of the meeting, manual face-to-face learning always takes place during study hours; lecturers and students meet and interact at the same time and space. All processes occur immediately so that lecturers and students can see their respective roles and responses in their entirety.

Meanwhile, in online activities, interactions through the media and lecturers and students are not in the same space, so they tend to be incomplete. From the description of the dynamics, it is felt an urgency to see how the role of lecturer leadership in the context of the influence that lecturers make on students as learning participants. Contextually with the new online learning model, lecturers have limitations in influencing students to achieve learning goals. Influence is the power or force used to change attitudes, behaviour, opinions, goals, needs, values, abilities, and actions to move in a specific direction (Wirawan, 2013). The task of influencing itself is inherent in implementing leadership because leadership is related to activities to impact others. Referring to a brief understanding of the terms relevant to this discussion, there is a sense of urgency in analyzing the tactics used by lecturers in their leadership in online learning activities during the Covid-19 Pandemic. Discussion of the problem is carried out with a qualitative approach. A qualitative approach is a method to explore and understand the meaning that a group of people ascribes to social or humanitarian problems (Creswel, 2017; Silitonga, 2020).

The qualitative approach is also understood as a research approach that is carried out fairly, requiring researchers to interact closely with research subjects and is also more oriented towards exploration and discovery and does not intend to test theories (Idrus, 2009). Data collection is carried out at universities by research interests. The main instrument in this study is the researcher (researcher as an instrument) based on the guidelines for the data collection techniques used. The concept of the researcher as an instrument is understood as a tool that can reveal various facts in the field. This is based on the opinion that there is no most flexible and appropriate tool to disclose qualitative data except the researchers themselves (Satori \& Komariah, 2011). Data collection is equipped with interview techniques, observation, and literature study. In this case, interviews were conducted with five informants who were considered to know the research problem. Comments were made in online learning activities. Then the literature study is based on various 
relevant references, including theoretical considerations and previous research results correlated with research problems.

\section{B. LITERATURE REVIEW}

A review of the literature related to this issue covers leadership, influence tactics, and learning primarily. First, regarding leadership, there are many opinions expressed by experts. Stogdill in Yukl (2015) states that the number of definitions of leadership is almost as many as the number of people trying to explain the concept. Yukl himself (2015) says leadership is a process to influence others to understand and agree with what needs to be done and how the task is carried out effectively and a method for facilitating individual and collective efforts to achieve common goals. Then leadership can be interpreted as what the leader does or the operation of leading a group and influencing the group in achieving its goals (Robbins \& Coulter, 2010: 146; Silitonga, 2019). Usman (2016) explains that the term leadership comes from the world leader, which according to The Oxford English Dictionary (1933), was only used in the early 1300s. Then the word leadership did not appear until the middle of the XVII century, both in political writing and controlling parliament in England. The word lead comes from the Anglo Saxon word, usually used in Northern European languages, which mean 'road or path of a ship's journey. Related leadership roles are typically associated with the organization.

Leadership effectiveness refers to success which is always correlated with the goals to be achieved within the organization. Plans are not limited to organizational goals but also include the goals of groups within the organization and personal goals. The effectiveness of leadership cannot be seen solely from one side, such as from the role of the leader, but cannot be separated from the followers' response. In the discussion of leadership, the context must include the part and potential of followers. Thus, the effectiveness of leadership is also related to the condition of following. Lecturer leadership refers to the general notion of leadership. Leadership is usually associated with performance. Kieu (2010) found that leadership is one of the most significant contributors to organizational performance. Purwoko (2018) states that lecturer performance is a synergistic element that must be developed to give birth to an educational process that is relevant to the demands of the situation, conditions and needs of the graduate user community. Lecturer leadership in that context is an activity to dynamic the class through the influence of lecturers so that the dynamics of the learning process can support learning objectives.

The dynamics carried out by lecturers are closely related to the dynamics of learning in online learning situations. Dimopoulos (2020) states that leaders face challenges in communication, trust-building, interpersonal development and technical skills, and group cohesiveness in online learning. Dimopoulos indicated that these barriers could be minimized through the use of transformational leadership models. This is in line with the findings of Jason (2000) that Transformational leadership is considered appropriate and able to encourage the creation of a multicultural culture. The realization of learning achievement is 
understood as the result of various factors. This context is analyzed from the aspect of the lecturer's leadership role through the quality of learning. Or lecturer in Citizenship Education courses. Lecturers with adequate competence and approach will be able to carry out the class leadership role well so that learning activities are carried out according to schedule and are more meaningful with a learning process that can encourage the achievement of learning objectives optimally. The role of lecturers in learning activities can be seen from the perspective of leadership, considering that learning activities are entirely in the management of the lecturers. Even though the learning approach model is student-centred, all activities are still under the authority of the lecturer. However active students are in the classroom, the process must be seen to realize the learning objectives, which can be seen as the lecturer's performance target.

Further understanding needs to be explored regarding influence which is closely related to the influence tactics used by leadership. From various perspectives, the notion of leadership is evident as leading and the things leaders do in influencing their followers to achieve organizational goals. Yukl (2015) mentions influence is seen as the core of leadership, and for someone to be an effective leader, he must be able to influence others to want to carry out specific requests. Then Daft (2010) further emphasizes the meaning of influence in leadership; only the perspective is related to employees and the organization. Daft stated that leadership means using influence to motivate employees to achieve organizational goals.

From the description of the notion of influence, it can be seen the importance of that influence for someone who, in this case, is seen in the context of leadership. Influence can be called the energy contained in a person functions to encourage others to do something they want. The concept of influence is distinguished from power and authority. Management involves the capacity of one party to influence others, while source involves rights, negatives, obligations, and duties related to a unique position in the organization (Yukl, 2015). Power and authority tend to be the capacity that a person, for example, a leader, has to influence others. Then the results of the capacity process are then responded to in the form of influences on others. Yukl (2015) asserts influence as the target's motive and perception about the agent's actions in the interaction process.

Furthermore, Yukl (2015) mentions that there are three results or responses to influence. First, influence can result in commitment from other parties in approval or support for requests from the influencer. Second, power can also produce compliance, namely the willingness to do things that the influencer wants. Still, the activity is characterized by apathy rather than enthusiasm, so that it provides little support. Furthermore, third, influence can produce resistance, namely, in actions against the influencer's request. In that case, it is described that the response is disinterested but trying to avoid not carrying it out. To achieve better results, influence tactics are needed. Influence tactics are behavioural patterns designed and implemented to create an influence that changes the target. Hall in Wirawan (2013) mentions that influencing tactics can be done using brutal tactics and soft tactics. 
Hard tactics influence behaviour by forcing and encouraging the target to obey the agent's orders or wishes. This tactic is considered to provide many obstacles to the relationship between the agent and the target. The following soft tactic is wise and constructive behaviour.

Wirawan (2013) mentions various types of influencing tactics. First, the legitimacy tactic is a tactic with the agent pattern showing the target that the agent occupies a specific position in the organization where the target is a subordinate or follower. In that condition, the target must fulfil the agent's orders or requests, and if the target does not comply, the agent can impose sanctions. The activities of the legitimacy tactics are further shown in the following table.

Table 1 Legitimacy Tactics Activities

\begin{tabular}{|c|l|}
\hline No & \multicolumn{1}{|c|}{ Activity } \\
\hline 1 & $\begin{array}{l}\text { Explain the position in the organization (read: lecturer as supervisor explains } \\
\text { the position as a supervisor with the authority and power to lead the class } \\
\text { and students as class members) }\end{array}$ \\
\hline 2 & $\begin{array}{l}\text { Mentioning the role of the leader is legitimate as a party that can impose } \\
\text { sanctions and assign tasks (read: lecturers can reprimand students and relate } \\
\text { the part of students in the assessment process for graduation or not passing } \\
\text { in lectures) }\end{array}$ \\
\hline
\end{tabular}

Source: Data Processed based on Definition of Wirawan (2013)

Furthermore, rational persuasion tactics are in the pattern of agents using data, facts, experiences, scientific theories, visions, missions, laws, regulations, work procedures to influence targets. The activities of rational persuasion tactics are shown in the following table.

Table 2 Activities of Rational Persuasion Tactics

\begin{tabular}{|c|l|}
\hline No. & \multicolumn{1}{|c|}{ Activity } \\
\hline 1 & $\begin{array}{l}\text { Demonstrate the basics of regulation and the organization's vision and } \\
\text { mission in the implementation of work (read: lecturers explain the basics of } \\
\text { learning materials to students) }\end{array}$ \\
\hline 2 & $\begin{array}{l}\text { Demonstrate logic and data that support understanding of work to support } \\
\text { the achievement of organizational goals (read: lecturers show factual facts, } \\
\text { realities of life, and descriptions of theories or concepts related to problems } \\
\text { encountered in lectures) }\end{array}$ \\
\hline
\end{tabular}

Source: Data Processed based on Definition of Wirawan (2013)

Next is the exchange tactic, namely the pattern of agents promising to give something or not giving something if the target fulfils or does not fulfil the agent's orders. The application of this exchange tactic is typically applied in a transactional leadership environment. The subsequent exchange tactical activities are shown in the following table. 
Table 3 Exchange Tactics Activities

\begin{tabular}{|c|l|}
\hline No. & \multicolumn{1}{|c|}{ Activity } \\
\hline 1 & $\begin{array}{l}\text { Promising certain rewards or benefits if members of the organization do } \\
\text { something according to organizational criteria (read: lecturers promise to } \\
\text { give good or bad assessments if students follow/do or otherwise ignore tasks } \\
\text { given by lecturers) }\end{array}$ \\
\hline 2 & $\begin{array}{l}\text { Concretely explaining rewards (read: lecturers detail the rewards that will be } \\
\text { given to students in their role in learning) }\end{array}$ \\
\hline
\end{tabular}

Source: Data Processed based on Definition of Wirawan (2013)

Another type of tactic is coalition tactics. The agent enlists the help of others to persuade or influence the target to comply with orders or fulfil the agent's expectations. Coalition tactical activities are then shown in the following table.

Table 4 Activities of Coalition Tactics

\begin{tabular}{|c|l|}
\hline No. & \multicolumn{1}{|c|}{ Activity } \\
\hline 1 & $\begin{array}{l}\text { Leaders persuade members of the organization to do something (read: } \\
\text { lecturers convince students to attend lectures well) }\end{array}$ \\
\hline 2 & $\begin{array}{l}\text { The leader explains the importance of cooperation (read: lecturers explain the } \\
\text { importance of collaboration between lecturers and students for the smooth } \\
\text { implementation of lectures) }\end{array}$ \\
\hline
\end{tabular}

Source: Data Processed based on Definition of Wirawan (2013)

Another tactic is asking superiors for support in activities asking for support or legitimacy (approval) from leaders before influencing targets. The tactical activities of asking for help are then shown in the following table.

Table 5 Tactical Activities Asking for Support

\begin{tabular}{|c|l|}
\hline No. & \multicolumn{1}{|c|}{ Activity } \\
\hline 1 & $\begin{array}{l}\text { Request support from superiors in the activity of asking for support/approval } \\
\text { of the implementation of influencing members of the organization (read: } \\
\text { lecturers ask for support from university leaders/deans/heads of departments } \\
\text { for teaching implementation) }\end{array}$ \\
\hline
\end{tabular}

Source: Data Processed based on Definition of Wirawan (2013)

Ingratiation tactics are agents trying to win over the target. They have positive feelings towards the agent, for example, by praising, extolling, saying he is a wise person, and having feelings of trust in the agent. This ingratiation tactic is considered less successful if, in reality, the target knows the agent is manipulating the conditions in his compliment. The activities of the take-over tactics are then shown in the following table. 
Table 6 Activities of Taking Hearts

\begin{tabular}{|c|l|}
\hline No & \multicolumn{1}{|c|}{ Activity } \\
\hline 1 & $\begin{array}{l}\text { Giving praise and elevating members of the organization as a party who can } \\
\text { be trusted in carrying out their duties (read: lecturers give credit and appoint } \\
\text { students as parties who pay attention to lecture material) }\end{array}$ \\
\hline 2 & $\begin{array}{l}\text { Mention members of the organization as supporting leaders (read: lecturers } \\
\text { mention students respect and are loyal to lecturers as lecturers) }\end{array}$ \\
\hline
\end{tabular}

Source: Data Processed based on Definition of Wirawan (2013)

There are other types of influence tactics. Personal request tactics, namely the agent uses good personal relationships, friendships, brotherhood, one-corporate relationships to influence the target. The activities of the individual request tactics are further shown in the following table.

Table 7 Activities of Personal Demand Tactics

\begin{tabular}{|c|l|}
\hline No & \multicolumn{1}{|c|}{ Activity } \\
\hline 1 & $\begin{array}{l}\text { Using personal relationships well in the image of a friend or relative (read: } \\
\text { lecturers use personal relationships well in the idea of a friend or relative) }\end{array}$ \\
\hline 2 & $\begin{array}{l}\text { Explaining the closeness of relationships with specific details such as having } \\
\text { known for a long time, having similar struggles, and other correspondence } \\
\text { (read: lecturers explain the intimacy of relationships with students with } \\
\text { specific details such as fellow nationals, have experienced the same experience } \\
\text { as students in facing difficulties from various activities following lectures, } \\
\text { etc.) }\end{array}$ \\
\hline
\end{tabular}

Source: Data Processed based on Definition of Wirawan (2013)

Furthermore, the co-optation tactic is in the pattern of agents involving targets in planning, implementing, and evaluating a program or activity to see that the agent's efforts involve the target. The actions of co-opting tactics are listed in the following table.

\section{Table 8 Activities of Co-opting Tactics}

\begin{tabular}{|c|l|}
\hline No & \multicolumn{1}{|c|}{ Activity } \\
\hline 1 & $\begin{array}{l}\text { Involving organizational members in planning, implementing, and evaluating } \\
\text { work programs (read: lecturers include students in planning learning } \\
\text { materials, involvement in learning through presentation activities) }\end{array}$ \\
\hline 2 & $\begin{array}{l}\text { Involve members of the organization to evaluate the program and provide } \\
\text { input on various rights related to the program (read: lecturers offer broad } \\
\text { opportunities for students to assess and provide advice in the learning } \\
\text { process) }\end{array}$ \\
\hline
\end{tabular}

Source: Data Processed based on Definition of Wirawan (2013)

The following is a suppression tactic, namely the pattern of agents using threats to give sanctions if they refuse to carry out orders, notification and strict treatment of repeating, controlling, evaluating whether the target carries out orders or not. The activities of the pressing tactics are then shown in the following table. 
Table 9 Pressing Tactics Activities

\begin{tabular}{|c|l|}
\hline No & \multicolumn{1}{|c|}{ Activity } \\
\hline 1 & $\begin{array}{l}\text { Explain and emphasize repeatedly related to sanctions that can be given to } \\
\text { members of the organization if they do not comply with the leader's orders } \\
\text { (read: lecturers explain and emphasize repeatedly sanctions to students if they } \\
\text { do not follow the lesson well) }\end{array}$ \\
\hline 2 & $\begin{array}{l}\text { Strictly control the activities of members of the organization and reprimand } \\
\text { and take action against members who commit violations (read: lecturers hold } \\
\text { the student's role slowly and give warnings and give sanctions to students who } \\
\text { do not follow the lesson well) }\end{array}$ \\
\hline
\end{tabular}

Source: Data Processed based on Definition of Wirawan (2013)

Another influencing tactic is the personal attraction tactic. This unique attraction tactic refers to Yukl's explanation in (Marianti 2011) based on asking to do something because he is a friend or because he is considered loyal. In the author's opinion, this unique attraction is related to the self-performance in leaders who can move members of the organization to do something the leader asks. The next private attraction tactic activity is shown in the following table.

Table 10 Activities of Personal Attractive Tactics

\begin{tabular}{|c|l|}
\hline No & \multicolumn{1}{|c|}{ Activity } \\
\hline 1 & $\begin{array}{l}\text { Having a certain charisma in the form of a superior personality as outlined in } \\
\text { words, deeds, and the view of the importance of goodness (read: lecturers have } \\
\text { a certain charisma in the form of a superior personality as outlined in words, } \\
\text { actions, and views the importance of distinction) }\end{array}$ \\
\hline 2 & $\begin{array}{l}\text { Having certain advantages in the form of a track record of performance, level } \\
\text { of personal achievement or specific achievements mentioned to support } \\
\text { organizational performance (read: lecturers have certain advantages such as } \\
\text { track records of lecturers' accomplishments and essential notes about lecturers } \\
\text { that are correlated in keeping the quality of learning that creates sympathy } \\
\text { college student) }\end{array}$ \\
\hline 3 & $\begin{array}{l}\text { Have the ability to manage classes, deliver presentations attractively, and can } \\
\text { create a fresh atmosphere in overcoming boredom }\end{array}$ \\
\hline
\end{tabular}

Source: Data Processed based on Yukl's Definition in Marianti (2011)

Further theoretical deepening is carried out on learning. Learning is an activity that involves lecturers and students in interaction in a particular learning environment. The learning process must use effective learning methods by the characteristics of the courses to achieve specific abilities specified in the systems to achieve a series of the fulfilment of graduate learning outcomes. Referring to the Minister of Education and Culture Regulation Number 3 of 2020 concerning National Standards for Higher Education, learning can be in the form of lecture activities, responses and tutorials, seminars, and practicum, practice, studio, workshop practice, or field practice. It's just that, in addition to these forms, forms of learning can also be added in the form of learning in the form of research, design, or 
development whose activities are under the guidance of lecturers in the context of developing attitudes, knowledge, skills, authentic experiences, as well as improving community welfare and national competitiveness.

Various demands and learning methods are basically aimed at realizing the quality of learning. Regarding this quality, Green in Papanthymou \& Darra (2017), mentions quality is a big and interesting challenge for higher education. According to Beckett \& Brooks (2008) in many countries and many cultures the issue of quality management has continued to be on the agenda of higher education. Quality management issues have become one of the most basic ingredients and forces in higher education around the world (Ganguly, 2015). Various policies and the development of learning methods were then carried out in realizing the intended quality. It is understood that the educational process, including learning activities, is an essential means of shaping the attitudes and behaviour of students. The learning process in schools is the best public policy tool to increase knowledge and skills (Parsel, 1979). There is the interaction between educators (read: lecturers) and students in the learning environment in learning activities. Referring to the implementation of online learning, the dynamics of the difference with offline learning are understood. Problems with online learning include limited mastery of information technology, inadequate infrastructure, limited internet access, unprepared use of the budget (Aji, 2020).

Online learning is usually characterized by an intense interaction model between lecturers and students and can also be less or less severe. The interaction model is intensely marked by direct communication through the exclusive use of media zoom meetings, cisco webex meetings, google meetings, or others. Meanwhile, interaction is less or not intensely usually in learning activities without direct communication applications. An example of this last model is using the google classroom or link application as media widely used today. Still, it may not be equipped with online communication and face-to-face facilities. The form of actualization of online learning also questions the psychological aspects and the attitude formation side of students. Examples of student attendance online can be with specific dynamics. The process is not enough just for students to have names as learning participants. Punctuality to enter on time, direct self-presentation, student responses to learning are also essential parts.

For this reason, institutional management is expected to encourage educators to have concerns and have the ability to achieve the attitude aspect of students even in online learning methods. Of course, academic freedom and scientific autonomy remain the domain of educators. Still, achieving psychological factors and forming student attitudes is part of the aspects that need special attention. On the other hand, online learning has its advantages. Siahaan notes in Wuryanto (2006) that one of the advantages of online education is that it increases interaction between lecturers and students because learning can be done anywhere and anytime in the broader scope. Basori (2017) added that learning by utilizing technology can help lecturers and students, especially learning management activities. Sriwiharjriyah et al. (2012) 
mention that. This information technology can act as a medium between students and lecturers who provide learning resources and means to streamline learning evaluation.

\section{RESULTS AND DISCUSSION}

Lecturer leadership in Civic Education learning is actualized through scheduled lectures and conducted online, referring to the new learning policy that replaced offline programs after the Covid-19 outbreak. In this activity, the lecturer transfers knowledge and the value system to the learning outcomes of subjects in supporting the learning outcomes of graduates. The reality of the Citizenship Education course, which is a national compulsory subject, mandates the formation of character and personality as Indonesian citizens.

Based on the dynamics of online learning, some various obstacles and opportunities need to get the attention of lecturers. In this context, of course, the role of students in supporting lecturers in achieving learning objectives cannot be separated. It's just that the role of the lecturer as a lecturer or, in this case, as an agent or leader is more prominent. The position of the lecturer is reviewed based on the tactics used in influencing students to support and follow the wishes of the lecturer to achieve learning/lecture goals. Students' existence in learning activities is carried out to realize the learning outcomes of subjects and in this series, including contributions to encourage behaviour, attitudes, and personality as citizens who are aware of loving the country and defending the country. The activities of lecturers influencing students are reviewed based on the tactics used by lecturers at all stages of learning activities, from the initial stage, the current stage, and the final step. Based on this, the analysis is carried out on all interactions in learning activities from the initial stage, implementation stage, to the final stage, as will be described further based on data collection and discussion of the data results.

In the early stages of lecture activities, various aspects are included. The initial activities of the lecture are filled with introductions and delivery of different activities carried out during one semester. The lecturer in this case also mentions the position of students as participants in lectures led by lecturers. The existence of lecturers is based on carrying out higher education management policies and thus carrying out the mandate of higher education leaders. In this activity, the lecturer also emphasised that the courses taught and followed by students were compulsory national learning and were mandated in the legislation. Lecturers also, in the initial activities, convey various directions and obligations of students. This includes lecturers sharing information about the tasks that will be given to students in ongoing lecture activities. In the initial introduction, the lecturer also conveys the target of the lecture in achieving the course objectives. The explanation is accompanied by an emphasis that students have obligations that must be carried out, and if they cannot fulfil them, they will be subject to sanctions. Lecturers give sanctions to students related to the results that students will receive at the end of lecture activities. Sanctions in the form of providing values become something that is 
considered rational by both lecturers and students. The lecturer's explanation gives a signal to students that the lecturer has the authority to assign tasks and carry out learning.

In contrast, students are required to do the jobs ordered by the lecturer and follow the lesson well. Related to that, lecturers use several tactics at once. First, the lecturer applies legitimacy tactics, which is reflected in the activities of the lecturer explaining his position in the class. In that case, the lecturer explains his existence as a supporting lecturer with authority to control the level and students as participants who must follow the provisions of the lecturer. Lecturers also use rational persuasion tactics, which are reflected in the explanation of the existence of the course as a mandate from the legislation and a description of the vision of the system that is correlated with character building with personality as a good citizen. In this regard, considering that in the initial lecture, the substance of the course has been entered, the lecturer explains various supporting theories and rationale for understanding multiple problems that occur around national life. The influence that lecturers have on students includes personal attraction tactics. This unique attraction becomes its own tactical, which refers to the self-actualized quality of a good attitude, self-confidence, and the addition of status or self-attribute. This personal attraction tactic includes being active in having a lecturer status, which is generally the status of a member of the TNI.

The influence of personal attractiveness is also attached to various attributes that exist in lecturers in general, including educational qualifications, suitability with science, and work status. The features inherent in the lecturers are essentially through the presentation of the lecturer at the beginning; students can see the capabilities of the lecturer as a lecturer in the course. There is a saying that the first impression is the main and the rest refers to the first impression. This impression does not need to be carried out in conveying the semester learning plans scheduled for each meeting from beginning to end. The lesson plan document is, of course, not just administrative data but contains the substance of the material and the level of contextualization with updated fabric and relevant tasks. The lecture contract is a part that lecturers usually have to convey to students at an early stage. The lecture contract contains an agreement between the lecturer and the student regarding things that must be done and should not be done. This process has involved rational persuasion tactics carried out by lecturers.

A detailed explanation, at least by emphasizing the critical parts that students must act on, becomes a means that can rationally facilitate the learning process. That way, students know the signs of lecture activities in the context of achieving learning outcomes. Regarding lecture signs, it becomes the basis for lecturers to provide rewards and punishments that are actualized in giving grades according to student activities for performance activities in learning. At this initial stage, the activities also include lecturers' mastery of learning facilities and infrastructure. When the lecture takes place online, students will pay close attention to the process carried out by the lecturer since entering the initial meeting as well as the smoothness in its 
implementation. In the context of lecturers being able to enter and follow the online process smoothly, describing lecturers as connected with information technology devices. The process continues with the use of features and various learning variations such as the use of animation, videos, presentation of learning support data, and others. The assessment is in the form of student appreciation for the lecturer concerned. Connections to IT are usually symmetrical with the ability of lecturers to access various scientific references. On the other hand, if the lecturer seems to be technologically stuttering, it reduces students' confidence in the lecturer. The Lecturer's mastery of this infrastructure can be seen as an influencing activity related to personal attraction tactics. Lecturers who have access to information technology activities have no problem with the matter of personal attractiveness. The Lecturer's mastery of the means of communication is correlated with the capacity of the lecturer as a lecturer. Lecturers who have access to information technology are perceived to carry out activities taking materials from online source facilitation. It's just that referring to the dynamics; some senior lecturers are less familiar with information technology tools and cannot access materials online. On several occasions, there were obstacles, and the lecturers did not know the disturbances that occurred. In the process, lecturers were assisted by students in the use of information technology devices and online access processes.

Attitudes and attention are part of complementing the leadership aspects of lecturers in learning activities. The attitude and attention referred to include the willingness of the lecturer to enter with the dynamics of students' existence with the problems surrounding their lives. Referring to the lecturer's explanation, in general, lecturers try to empathize with students and thus, lecturers have entered into the implementation of personal request tactics. According to the lecturer's explanation, they are empathizing activities with students to establish closeness. The lecturers explained that the lecturers realized that there was a demand for the lecturer to explore the inner atmosphere of students who thought they were faced with many responsibilities and learning tasks. Lecturers in this context are expected to "want to know" and not otherwise "don't want to know." Want to know what is meant here does not mean that the lecturer then immediately gives concessions and reduces the assignment of his courses. Want to know should be interpreted as a response to empathize followed by activities to inspire the spirit of students to be more solid and more confident in their potential. Exemplary becomes part of the embodiment of the lecturer's attitude and self-attention.

Simply put, when starting and ending classes, discipline is done promptly. The appearance of oneself in terms of neatness in dressing is also a part that should not be missed. Even though the media, the lecturer's appearance can be seen through the monitor screen. This is complemented by the consistency of the lecturers towards the learning contract and various provisions that have been submitted. Suppose it is determined that all focus on learning, lest the lecturers themselves do contradictory things, such as receiving phone calls online. The lecturer's self-national insight can be observed from his views on the substance of the subject matter and his utterances. 
The Citizenship Education course is related to citizen orientation towards the nation and state and the demands that need to be made as citizens. Lecturers in that context convey various opinions. The national exposure regarding its views is based on the nation-state and compliance with the laws imposed by the state. Lecturers should avoid attitudes and behaviours that do not prioritize national orientation. National orientation can be done in simple ways, among others, by conveying national greetings and greetings that expressly show the diversity of the Indonesian people when starting and ending learning.

Based on the various influencing tactics carried out in the early stages of activities, it has been sufficient to lead students to understand the existence of lecturers as course supervisors. Students can also accept their obligations to participate in various programs delivered by lecturers, including in providing assignments to support efforts to achieve learning objectives. It's just that in the initial activities, students also saw several lecturers who were considered from the older generation, not so perfect in the use of information technology facilities with various dynamics. Even though at the same time, students, in general, are very familiar with access to information technology tools and their use in online processes. Such conditions are part of the student acceptance process for lecturers.

From the description mentioned above, lecturers use various uses of influencing tactics in learning in the early stages of lectures. The influence tactics used by the lecturer as described above are then described in the following table.

Table 11 Influencing Tactics in the Early Stages of Lectures

\begin{tabular}{|c|c|}
\hline No & Tactic Type \\
\hline 1 & Legitimacy \\
\hline 2 & Personal Attraction \\
\hline 3 & Rational persuasion \\
\hline 4 & Personal Request \\
\hline
\end{tabular}

Source: Data processed, 2020

Lecture activities can also be seen on the running stage. At this stage, a move that refers to the implementation of learning includes all learning materials by the allocation and learning schedule in one semester. At the beginning of the introductory activity, some of the learning materials had already been delivered, but they were more introductory. In the running stage, it is the implementation of providing material comprehensively covering the second meeting until the end of the fourteenth meeting of lecture activities. In a long period in the running stage, the lecturer involves students by taking turns to schedule presentations. Time was allocated for about forty minutes, accompanied by a question and answer activity from the scheduled allocation of one hundred minutes. After that, the lecturer took over and delivered the substance of the subject matter of each meeting and correlated it with presentations made by students.

The implementation of student involvement in turns can be seen as implementing the effect of co-opting tactics. Co-optation tactics can be seen as the 
actualization of placing students as "individuals" or being rewarded for presenting the subject. In this pattern of co-opting tactics, lecturers carry out student empowerment in learning activities. This is in line with the concept of studentcentred learning. This means that lecturers involve student participation in that context so that they play a significant role in all learning activities. Student empowerment can be applied, among others, by scheduling them in turns to make presentations, and at the same time, other students prepare themselves to respond to their friends' presentations. The responses include asking questions or adding explanations. Providing opportunities for students to take turns presenting activities, makes fellow students want to see how their friends make presentations. The desire of students to see the appearance of other students with a stimulus affects the increase in learning motivation. The intended stimulus can be strengthened by giving appreciation for their role. The opportunity to ask questions, be a moderator, or provide additional explanations is part of the performance or assessment of student participation in class. Empowerment of students in learning activities can also be seen in the perspective of assignments to them. In this assignment, the proportion must be seen. This proportion includes a sense of justice and demands for rewards and punishments. According to the lecturer's explanation, although explaining the general sanctions, basically the lecturers did not emphasize it too much considering the students' responses to the assignments given. Lecturers even provide a lot of praise to students who can carry out tasks well. The implementation of this condition can be seen as the implementation of the tactic of taking heart. This tactic was very efficient in encouraging other students to show cooperative performance, as their friends received praise from the lecturer.

Referring to the object of research at universities whose students are generally academically potential, this co-opting tactic is quite adequate, and there are no obstacles to representative students. Because of their academic potential, students, in general, can convey the substance of the learning material quite adequately and by the schedule of the subject matter. Students, because information technology networks, in general, have accessed them, can display the substance of the material in front of lecturers and students. Regarding the activities of this running stage that take place regularly, several lecturers admitted that there was a monotonous situation on several occasions. It seemed that students were presented with repetitive activities. Lecturers can be trapped in the rhythm of students with a dull impression. Students often seem to feel bored with the presentation of the topic of discussion. The subject of a debate is constantly changing, but referring to experience, students perceive that learning materials seem repetitive. Regarding the student's boredom, such a condition feels natural.

There is a potential for learning enthusiasm to decrease. For this reason, lecturers need to provide motivation. Giving motivation in this context is done by lecturers by applying rational persuasion tactics. Encouraging is done in various ways. The designation of the actual condition of the dynamics of the problems faced by this nation and the demands of all country components starting from each 
individual and including students is one of the techniques that can be chosen. This means that in this context, the lecturer reminds students that their role is vital and is awaited for its actualization, beginning with an understanding of the theory and actual problems surrounding their lives. Variations in learning techniques can mean interludes in making fresh humour. This activity can be seen as the influence of personal attraction tactics as well. A good mood can make the atmosphere fresher. It's just important to pay attention to the humour sensor as a tool that melts the atmosphere but is chosen (Silitonga, 2008). Kick humour does not even become a tumour. These changes can occur when comedy is done in excess. In general, lecturers explain that it is necessary to avoid the impression of lecturers being comedians. It is also essential to prevent conveying humour that seems dirty and harassing certain tribes or communities from the community. The avoidance of the impression of harassment is intended primarily to avoid various attributes or state identities.

The delivery of learning materials, in general, is also influenced by students' perceptions of national leaders who sit in government, and it is also possible for leaders in the regions. Students who have high confidence in national leadership or leadership in government tend to be more receptive to learning programs and criticise actual problems in social reality. Meanwhile, students who lack confidence in the government's government usually do not show high enthusiasm for learning materials. If they even pay attention, they are generally eager to criticize government policies from the perspective of no good that the state has done to the people. Based on the topic of discussion, the theory and substance of the learning material are usually conveyed. However, according to experience, students always relate it to contextual conditions. Students typically ask questions or respond critically to actual problems. Students are now familiar with information technology and are always connected to various issues at the national and regional levels. This is a challenge for lecturers. Responding to multiple dynamics in students, lecturers are required to balance them by participating in the facilitation of the advancement of information technology. This connection can be actualized, among other things, by showing articles, reviews, or news reports that are relevant to the topic of discussion. Lecturer skills connected with information technology and its facilitation can maintain student confidence, as previously mentioned related to personal attraction tactics.

Connected with information technology devices is also related to the scientific mastery of lecturers. Lecturers are required to have the breadth and depth of scientific substance. In particular, the Civic Education learning material demands that the discussion be contextualized with social reality. A Lecturer's mastery of contextual issues can encourage students' level of trust in lecturers and become the glue that motivates students to participate in learning enthusiastically. It's just that related to this context, the aspect that lecturers do is show evidence and the basis for various dynamics of national problems and relations between nations and the role of government in the representation of the state. That way the efforts made by the lecturer can be seen as a form of applying the influence of rational persuasion tactics. 
Lecturer's scientific mastery is correlated with his attitude and attention to the nation and state. Lecturers must of course be based on their orientation to the love of Indonesia. Such attitude and attention is very basic. Lecturers who do not have a high national orientation certainly do not meet the criteria for being able to become lecturers in Citizenship Education.

Citizenship Education courses are part of personality formation so that citizens can contribute to their nation and country. Without a strong foundation of love or national and state orientation, how is it possible for lecturers to transfer personality values as mandated in learning. The attitude and attention of the lecturer who has a high orientation to the nation and state is based on his understanding of the theory and its correlation with policies issued by the government and the dynamics of social problems. Lecturers can see various conditions that occur in students. A neutral and scientific theory-based view is usually the answer to the dynamics of students' perspectives on national leadership and different government management practices. With this neutrality and theoretical basis, lecturers remain objective in conveying their views in responding to student responses and questions. With the attitude and attention of the lecturer, students are more receptive to learning that learning activities are not a form of indoctrination or a stamp of justification for government policies but can see various problems critically.

The objective attitude of the lecturer does not mean that the lecturer is always pro or always against the students. Say when you are pro to students, it does not mean that lecturers always fully accept the views of students who criticize government policies. If the student's idea is wrong, the lecturer must correct it, and the explanation is based on logical arguments. Lecturers avoid the "basic" argument model or use the power approach of the lecturer's position. The basis used in answering questions or responding to students is through a logical process to theory and argument, and this method is applying rational persuasion tactics.

The application of the rational persuasion tactic was further applied by the lecturers and responded to the views that did not agree with the prohibition of "communism" in Indonesia because the ideology became part of the prevailing ideology in the world. To this view, lecturers can respond by mentioning the theory of the nature of the state. One of the characteristics of the state is an actualized monopoly with authority to determine whether something is good or bad for the people. The notion of "communism", even though it is globally recognized as part of the state's way of thinking, for Indonesia regarding this understanding, has been a black record based on history. The state determines that this understanding is prohibited in Indonesia. The attitude and attention of the lecturers also include observing the attitudes and behaviour of students. Learning Citizenship Education, however, is related to the development of the self-character of the nation's children. In online learning activities that require direct interaction, for example, through the Zoom application, Google Meet, Cisco Webex Meetings, or others, network problems exist. As an implication, sometimes students cannot show their faces and themselves directly. Some students just display their profile that has been set in the 
application. Such conditions should get the lecturer's attention by reminding students to be able to present themselves directly.

Some students sometimes reason that they cannot present themselves directly due to network constraints. In this context, the lecturer applies personal request tactics. Lecturers try to position themselves as students who the network may constrain. It is very logical, and students may do experience problems, or there are network problems. If there are network problems, of course, students cannot be forced to show themselves in front of the monitor screen. However, the concern of the lecturers in asking the condition of students who cannot show their faces directly should be emphasized. Including lecturers needs to ask students who experience network problems, resulting in students being late in joining learning activities. The attention of the lecturers is no exception to the presence of students regarding the clothes worn and related to manners in general. Even though learning is online, it is also essential for students to look presentable and wear proper attire. Students should not be allowed to wear T-shirts or wear clothes that do not reflect their appropriateness as students, even though their position is at home during online learning. In the end, the attitude and attention of the lecturers are also related to the lecturer's self example, which is related to the influence of personal attraction tactics. The intended model includes an attitude that shows discipline and consistency in words and actions. The field could be seen from the use of time, consistently giving assessments of student assignments if they had previously promised to provide grades and various lecturer activities. The examples include speech, politeness, and attitudes in responding to students.

The actualization of the personal attraction made by the lecturer in the activity seeks to display good values, which are reflected in the attitudes and services provided by the lecturer. This service also includes providing opportunities for students outside of the learning schedule. In procedural terms and activities, lectures are regularly scheduled every week. There is a mention that online learning can be done anytime and anywhere with a broad scope. The description of the breadth of learning content with such an online method cannot be denied. It's just that related to learning; the activities are regularly scheduled every week at the same time and with clear participants, namely the average class number of 40 people. It cannot be denied that there are also limitations for some students to respond or ask something related to the substance of learning. The actualization of personal attractiveness is very prominent in facilitating students to provide their services. According to the lecturers, on average, they provide access to contact lecturers outside of the lecture schedule through direct communication via telephone, through WhatsApp communication, and or via electronic mail. In its implementation, several students take advantage of this service by contacting the lecturer asking questions that, according to students, need a different explanation from the lecturer.

Regarding the actualization of personal attractiveness, the activities are required for all activities and interactions between lecturers and students in learning activities. The completion is also included in fair treatment and shows a transparent 
pattern of assessment to students. Transparency in the evaluation of lecturers can be done, among others, by announcing the results of the midterm exams. Clarity can also be done by telling the score obtained from the results of student performance, for example, the results of student presentations. For example, three students make presentations. Usually, there are differences in the way or outcomes of the presentations. For that, the lecturer can determine the results of the value for the three students who make presentations. In the implementation of assessment transparency, skills in providing this assessment become something that feels important. Lecturers try to avoid giving and announcing the results of grades; it turns out that they are not based on fair considerations or not based on specific criteria. With the basis of experience and willingness to master the field of work, the skills in this assessment will be achieved by lecturers.

Transparency of this value needs to be done by lecturers; it can be seen as part of socializing student scores. In this context, value announcements are carried out routinely by ongoing activities. The recording should not be left behind because it can affect student perceptions. Lecturers who are trusted to teach lectures in several classes are recorded separately so as not to get mixed up. Recording scores regularly is intended so that all data is recorded and there are no errors in the assessment. In the end, the achievement of student scores will be announced at the end of the lecture. In that context, there is usually an opportunity for students to ask about their score. Do not let it happen that students do not explain, do not know how lecturers assess student work, and there is no track record of student scores. With daily score announcements regularly, students can correct the final grade announcements that do not match the daily grade records. In this aspect of student activity assessment, it is also essential for lecturers to build student awareness by applying rational persuasion tactics. Good tactics in activities explain that these activities are correlated with activities of daily life. There is always an ongoing assessment in daily activities in social order and organizational processes in the world of work.

The evaluation is manifested in respect for students as part of community members based on their roles, attitudes, and behaviour. Student empowerment essentially activates students to be involved in learning activities. It's just that according to the view of the lecturer that it is crucial to see here so that the lecturer pays attention to his role. Don't let there be an impression that the lecturers just have to "have fun" or delegate the learning tasks to students. This impression becomes unavoidable when the lecturer does not take any role except to record student activities or just open and close classes in each learning schedule. Lecturers still manage time so that there is a session for giving explanations and concluding things discussed by students. There may be critical parts that have not been answered thoroughly; with their knowledge, the lecturer is expected to complete them to satisfy the curiosity of students and fulfil the learning interaction process.

From the description mentioned above, lecturers use various uses of influencing tactics in learning at the current stage. The influence tactics used by the lecturers are then described in the following table. 
Table 12 Influencing Tactics in the Walking Lecture Stage

\begin{tabular}{|c|c|}
\hline No & Tactic Type \\
\hline 1 & Co-opt \\
\hline 2 & Rational persuasion \\
\hline 3 & Personal attraction \\
\hline 4 & Taking heart \\
\hline 5 & Personal request \\
\hline
\end{tabular}

Source: Data processed, 2020

The terms related to learning achievements and rounding done by lecturers are in the final stages of class learning activities. There will also be the last exam activity. The lecturer will remind students to prepare themselves for exam activities which ultimately leads to the authority of the lecturer in providing an assessment of student learning achievements. Related to that, lecturers run the tactics of legitimacy and rational persuasion at the same time. Legitimacy tactics are more of an explanation of the end of lecture activities. Good persuasion tactics related to students' logic will face the value of lectures based on student readiness in final exam activities. The process is accompanied by the implementation of giving students final grades for the role of students in learning activities and the results obtained by students. Giving this value, of course, must refer to the performance of students from the beginning to the end of the learning activity. Before the scores are sent to the college administration where they teach, the lecturer first conveys the lecturer's assessment to students and allows them to complain or question the products that will be announced. The dynamics shown by this lecturer are still part of the description of the lecturer's service to students, and with good service, it shows that the process has been carried out using personal attraction tactics. The lecturers' rational persuasion tactics are also reflected in the use of theoretical descriptions and the lecturers' experiences in explaining the problems of national living conditions associated with the demands of citizens' behaviour towards the state. In the final lecture activities, the lecturers also still convey the subject matter related to the substance of the lecture; the lecturer describes the reference theories and the necessary analysis. In ending lecture activities, lecturers also try to build certain rationality. Lecturers also show an attitude and concern for taking sides with students, including fellow citizens and correlated with their importance in themselves and the nation's next generation. In this context, the lecturer also applies rational persuasion tactics and personal request tactics. Lecturers, in that case, try to build good relations with students in the frame of compatriots and reasonable persuasion tactics in the form of opening awareness of the challenges of students as the nation's next generation. At the final meeting, lecturers see the urgency and take advantage of the lecture closing session by emphasizing the importance of their role as academics and as future generations of the nation.

The most crucial part of implementing leadership is the achievement of goals. In the context of learning, the intended objective concerns the learning outcomes of 
subjects correlated with graduates' learning outcomes. The purpose of the lecturer in the context of class leadership is to achieve integration between student achievements as individuals and student achievements in general which is in line with the lecturer's goals in carrying out classroom leadership. The purpose of graduation is not the only learning target. From the administrative aspect, the average score received by students is B (good) and above. The achievement of the average score with a grade of B and above can be seen as a form of influence of the lecturer's influence tactics to achieve the target. However, in this context, it is necessary to emphasize that, especially for Citizenship Education courses, it is essential to see the actualization of the learning process to form a student mindset. This context is the most critical part of the implementation of the learning program. The formation of a stand is illustrated in increasing student attitudes and behaviour who increasingly have a national and state orientation. The actualization of these attitudes and behaviours in their daily lives includes the willingness to develop a polite attitude, be more tolerant, respect diversity, be determined to obey the law, be disciplined, and maintain self-respect as children of the nation who carry out the mandate to become the nation's next generation.

From the description mentioned above, lecturers use various uses of influencing tactics in learning at the current stage. The influence tactics used by the lecturers are then described in the following table.

Table 13 Influencing Tactics in the Final Stage of Lectures

\begin{tabular}{|c|c|}
\hline No & Tactic Type \\
\hline 1 & Legitimacy \\
\hline 2 & Rational persuasion \\
\hline 3 & Personal attraction \\
\hline 4 & Personal request \\
\hline
\end{tabular}

Source: Data processed, 2020

\section{CONCLUSION}

Based on the results of the data and discussion, it can be concluded that the leadership of lecturers in Civic Education learning is faced with the conditions of the Covid-19 Pandemic, including legitimacy tactics, rational persuasion, personal attraction, co-optation, ingratiation, and personal requests. Of the various tactics applied by lecturers, some of them are types of tactics inherent in carrying out their duties as lecturers, such as tactics of legitimacy and personal attraction. In addition, their implementation is very demanding on the role of lecturers. Furthermore, based on the discussion, it is also known that the learning process is influenced by the dynamics of the lecturer's ability to access information technology devices and network conditions during learning. For this reason, it is recommended that lecturers not lag in the power of students to access information technology to support students' trust in lecturers as well as in the context of lecturers' understanding of the dynamic 
conditions of network constraints or the condition of students who are less enthusiastic in learning.

\section{REFERENCES}

1. Aji, R. H. S. (2020). Dampak COVID-19 pada Pendidikan di Indonesia: Sekolah, Keterampilan, dan Proses Pembelajaran. Salam: Jurnal Sosial dan Budaya Syari, 7(5), 395-402.

2. Becket, N., \& Brookes, M. (2008). Quality management practice in higher education-What quality are we actually enhancing?. Journal of Hospitality, Leisure, Sports and Tourism Education (Pre-2012), 7(1), 40.

3. Chairani, I. (2020). Dampak Pandemi Covid-19 Dalam Perspektif Gender di Indonesia. Jurnal Kependudukan Indonesia, 39-42.

4. Creswell, J. W. (2017). Research Design Pendekatan Kualitatif, Kuantitatif, dan Mixed. Bandung: Pustaka Pelajar.

5. Dimopoulos, A. (2020). Educational Leadership Effectiveness. Is it a Matter of a Leader's Characteristics, Behaviors, or Leadership Style?. Journal of Economics and Management Sciences, 3(1), 13-13.

6. Ganguly, A. (2015). Exploring Total Quality Management (TQM) Approaches in Higher Education Institutions in a Globalized Environment-Case Analysis of UK and Sweden. British Journal of Education, 3(7).

7. Idrus, M. (2009). Metode penelitian ilmu sosial.

8. Jason, M. H. (2000). The Role of the Principal as Transformational Leader in a Multicultural Learning Community. The High School Journal, 83(3), 1-9.

9. Kieu, H. Q. (2010). Leadership Styles and Organizational Performance: A Predictive Analysis. The University of Phoenix.

10. Marianti, M. M. (2011). Kekuasaan dan Taktik Mempengaruhi Orang Lain Dalam Organisasi. Jurnal Administrasi Bisnis, 7(1).

11. Bernik, M., Sondari, M., \& Indika, D. R. (2017). Model of Quality Management System to Maintain Quality Consistency in Higher Education. Review of Integrative Business and Economics Research, 6(04), 235-242.

12. Persell, C. H. (1979). Education and inequality: The Roots and Results of Stratification in America's Schools. Collier-Macmillan.

13. Purwoko, S. (2018). Pengaruh Kepemimpinan Kepala Sekolah, Komitmen Guru, Disiplin Kerja Guru, dan Budaya Sekolah Terhadap Kinerja Guru SMK. Jurnal Akuntabilitas Manajemen Pendidikan, 6(2), 150-162.

14. Riyana, C., \& Pd, M. (2020). Konsep Pembelajaran Online. Modul Pembelajaran OnLine, 1.

15. Robbins, S. P., \& Coulter, M. (2010). Manajemen. Erlangga: Jakarta.

16. Satori, D. \& Komariah, A. (2011). Teori dan Landasan Pendidikan Kewarganegaraan. Bandung: Alfabeta.

17. Silitonga, T. B. (2008). Dasar-dasar Guru Serdadu: Praksis dan Eksis menjadi Pengajar Tentara. Yogyakarta: Aditya Media.

18. Silitonga, T. B. (2019). Kepemimpindan: Teori dan Praksis. Bogor: Unhan Press. 
19. Silitonga, T. B. et al. (2020). Evaluation of Overseas Field Study Program at the Indonesia Defense University. International Journal of Innovation, Creativity and Change, 12(10).

20. Silitonga, T. B. (2020). Perancangan dan Penulisan Karya Ilmiah: Proposal Penelitian, Skripsi, Tesis, dan Disertasi. Bogor: Unhan Press.

21. Usman, H. (2016). Manajemen: Teori, Praktik, dan Riset Pendidikan. Jakarta: Bumi Aksara.

22. Wirawan, D. (2013). Kepemimpinan: Teori, Psikologi, Perilaku Organisasi, Aplikasi dan Penelitian. Jakarta: Rajagrafindo Persada.

23. Yukl, G. (2015). Kepemimpinan Dalam Organisasi. Jakarta: Indeks. 